\author{
Crossing the Border: International Journal of Interdisciplinary Studies \\ Volume 5; Number 2; 15 July 2017 \\ ISSN 2350-8752 (Print); ISSN 2350-8922 (Online)
}

\title{
NON-NATIVE ACCENT, FAVORITISM AND THE LAW
}

\author{
Dr. Rahul Chakraborty (USA)
}

\begin{abstract}
Social science has predominantly discussed accent bias against non-native speakers, although not always. In this paper, positive consequences and favoritism of non-native accent will be reviewed along with the legal provision available in the USA to counter accent based discrimination. Specifically, this paper will present how listeners exhibited preferential treatments towards speakers with non-native accent and how some nonnative speakers are more immune to negative discrimination. Brief introduction to Title VII of the 1964 Civil Rights Act will also be presented as a potential legal provision available to employees, students and to anyone if they are discriminated against due to their non-native accent.
\end{abstract}

KEYWORDS: Accent; discrimination; accent modification; bilingualism; second language

\section{INTRODUCTION}

Usually speakers' accent help convey several critical information about their identity including geographical, socio-economic, and ethnic background (Labov 2006). Listeners use phonetic, phonological, and prosodic qualities of speakers' accent to derive critical information about the speaker's personality (Dailey et al 2005 et al. 2005). In the US, several factors probably have contributed to stigmatizing and negativestereotyping of speakers with non-native or foreign-accented English,including, the not-so-healthy U.S. vocational options, economic volatility, high unemploymentrates, ever increasing resentment towards job exports to foreign countries, motivated media coverage against the outsourcing economyof call centers, global political unrests and war, terrorism and religious tension along with negative publicity in media about competence and professionalism of employees with nonnative accent (Modic, 2007; Sandberg, 2007).There are reports where people with non-native accent are perceived as impoverished language users, even though language proficiency, speech intelligibility, comprehensibility and accent have a quasi-dependentrelationship (Gluszek \& Dovidio, 2010a,b) and people with distinct non-native accent might even have high language proficiency and comprehensibility in English (Rubin \& Smith, 1990).Frequently, speakers with non-native accent are consideredless trustworthy, less industrious, less intelligent, less competent and of lower social status (Edwards, 1982; Gluszek\&Dovidio, 2010a,b; Matsuda, 1991; Ng \&Bradac, 1993). Such accent related biases lead to stereotype formation not only in the corporate sectors, even academic and entertainment industries have extensively 


\section{Crossing the Border: International Journal of Interdisciplinary Studies}

reported detrimental consequences of accent related biases (Gluszek \& Dovidio , 2010a,b). In this review note, along with a brief overview of widely reported biases and discriminationagainst non-native accent, positive perception or favoritism associated with non-native accent and legal aspects of accent related discrimination will be reviewed.

\section{NON-NATIVE ACCENT AND BIASES}

Globally, more non-native speakers of English exist than native English speakers (Bloch and Starks, 1999) and yet the issue of accent related biases, discrimination, stigma and stereotyping is widely prevalent; the social science literature, in last 50 years, has extensively reported negative perception and prejudices towards speakers with non-native accent (Cargile and Giles, 1997; Dixon et al., 2002; Fuertes, Gottdiener, Martin, Gilbert, \& Giles, 2012; Giles, 1970; Edwards, 1999; Giles and Billings, 2004; Lippi-Green, 1994; Stewart et al., 1985). One of the reasons why accent bias occurs could be because people evaluate others based not only on their appearance, but also on how they speak. "Accent" refers to pronunciation differences (Hosoda et al., 2007) or those in power are perceived as speaking "normal, unaccented English" and any speech that differs is called an accent (Wolfarm, 1999). However, even though everyone speaks with an accent, only the minority or less powerful people are discriminated against (Matsuda, 1991). Accent bias is frequently subconscious but could also be a conscious attitude towards the non-native speakers not only in the workplace but also could be observed everywhere (Lou, 1994). Nonnative accent is known to evoke biases which promotes stigmatization and stereotype formations (Cargile and Giles, 1997; Dixon et al., 2002; Fuertes, Gottdiener, Martin, Gilbert, \& Giles, 2012; Giles, 1970; Edwards, 1999; Giles and Billings, 2004; LippiGreen, 1994; Stewart et al.,1985). Even though non-native speakers' language performance might not be inferior to any native speaker, frequently speakers with non-native accents are considered as less intelligent, less loyal, less competent, of lower status, and poor language users (Gluszek \& Dovidio, 2010a,b; Ng \& Bradac, 1993).

Academic sectors are not immune to such discrimination (Ford, 1984). Students of color with non-native accent in English in public primary and secondary schools (K-12 classes) also encounter biases (Walsh, 1991). Even a minor accent variation is known to trigger racial stereotypes and discriminatory attitudes (Ford, 1984). Discrimination against non-native accent has been reported at all academic levels (Walsh, 1991; Ford, 1984) and with various speakers with or without colors (Lindemann, 2005). For example, bias against speakers using English with Asian accent has been extensively reported where Chinese and Southeast Asian accented English have been associated with "least positive" and "less able to communicate well" (Hosada, 2007; Sharon G. Goto et al., 2002). Listeners even mentioned that Asian influenced English creates "anxiety, uneasiness, and discomfort" (Hosada, 2007; Sharon G. Goto et al., 2002). English speakers with Asian accent are perceived less favorably and are considered to be less effective and impoverished communicators (Hosoda \& Stone-Romero, 2010).Mexican and Chinese English speakers were described as most incorrect speakers and were negatively stigmatized (Lindemann, 2005).

In the US, variation of similar reports have been found against speakers with 
Spanish accented English (Brenan \& Brenan, 1981), Arabic accented English (Parkinson, 2007), African American English(Hewett, 1971; Crowl \& MacGinitie, 1974; Granger, Quay \& Verner, 1977; Blake \& Cutler, 2003). Accent bias has also been known to influence Charter school admission process (Hewett, 1971; Cobb \& Glass, 1999). Preference for Standard American English is overtly present in the US academic sectors (Rubin \& Smith, 1990). Among the undergraduate students in the US, English speakers with Spanish and Chinese accent were considered incorrect English speakers and were negatively stigmatized, but English from Germany, France and Italy were perceived speaking English most correctly and were the least stigmatized (Lindemann, 2005). It should also be noted that according to upside of accents hypothesis, Americans are not reflexively or inherentlyagainst any outgroup features or community as long as the non-natives attempt to assimilate to mainstream American linguistic culture (Hopkins, 2014). However, even though accent bias as a topic has been widely discussed (Neuliep \& Speten-Hansen, 2013; Giles, 1971), the field of Speech Language Pathology has predominantly focused on accent modification procedures/programs(Shah, 2012) and offered only a cursory attention to the issue of accent related biases (Chakraborty, 2015).

\section{POSITIVE PERCEPTION FOR SPEAKERS WITH NON-NATIVE ACCENT}

Positive perception, surfaced as maximum favoritism and trustworthiness, is usually assigned to accents that are listeners' own or something closest to their own accent (Hurt and Weaver 1972; Mulac et al. 1974; Ryan and Sebastian 1980; Edwards 1982; Coupland and Bishop 2007; Lev-Ari and Keysar 2010). Social identity theory and ethnocentrism have extensively explained such in-group affinity or own-group bias (refs). An own-race bias for voice had been reported by Perrachione et al. (2010) where White and Black Americans were asked to categorize the race of the speakers. The participants were relatively accurate at categorizing the race of the speakers and both the experimental groups exhibited an advantage of identifying their own racial group. Perrachione et al. (2010) concluded that in comparison to the supralaryngeal vocal structure of the 2 races, the dialect of the speakers predominantly influenced the accuracy of their judgments. Even though accent is a sociolinguistic construct closely associated with variables usually beyond a speaker's overt realization, biases, prejudices and discriminatory behaviors are arbitrarily associated with non-native accents (Olivia Corona, William Hammers, Sallie Hobbs, Analisa Martinez, Christina Romero, Rahul Chakraborty, 2016).

Relatively fewerstudies report that listeners' discrimination sometimeseven generate a favorableoutcome.For example, in the U.S., some speakers with non-native accent are ranked higher in the social tier; English speakerswith British or French accent are perceivedas well-educated, sophisticated and cosmopolitan (Cargile, 2000; Stewart, Ryan \& Giles, 1985). Similar results were reported by Lindemann (2005). At an undergraduate program in the USA, different variations of English from across the globe were presented to native speakers of English. The stimuli included English samples of speakers from Australia, Canada, China, England, France, Germany, India, Ireland, Italy, Jamaica, Japan, Mexico, Russia, and Spain. A significant variability in accent rating was observed. Samples produced by non-native speakers from Germany, France and Italy were considered the most correct English and the speakers were least stigmatized compared to English produced by speakers from 


\section{Crossing the Border: International Journal of Interdisciplinary Studies}

Mexico and China. Even in the academic sectors, students with non-native accent in English were asked more often to undergo accent modification compared to students who speak other languages with non-native accent (Levy \& Crowley, 2012). Krings and Olivares (2007) reported that every foreign ethnic group was discriminated, however, employers' prejudice towards second-generation immigrants during job interviews resulted in elimination for employment. Thus, employers' accent-biases was beneficial for some ethnic groups and detrimental for some; employer's accent biases results in workplace discrimination. Clearly, not all accents are graded equal.

Several arguments have been floated to explain why at times an individual or a group do not get subjected to negative evaluation or discrimination or prejudice. According to the justification-suppression model (JSM; Crandall \& Eshleman, 2003), at times, overt behaviors enveloped in prejudice are suppressed to project liberalism, humanitarianism and social equality. Absence of discriminatory attitude might also be due to the desire to maintain and promote a non-prejudiced self-image and antiprejudice or "political correctness" (Crandall \& Eshleman, 2003). It has also been reported that when individuals do not "fit" stereotypical perceptions, there is less likelihood that negative and discriminatory stereotypes will be applied (King, Shapiro, Hebl, Singletary, \& Turner, 2006; Brewer, 1988). For example, obese people are less likely to be negatively stereotyped and discriminated if their attire is inconsistent with stereotypes of obesity (King, Shapiro, Hebl, Singletary \& Turner, 2006).

Clearly, certain stereotypes are rated more favorably.It has been reported that speakers' accent can contribute to the sense of service authenticity; when French is spoken with British accent in English pubs in France, customer satisfaction increases (Kraak \& Holmqvist, 2016). Several other studies have also echoed similar conclusions. Edwards (1982) reported that listeners rated speakers with nonnative-accent more favorably on the dimension of solidarity towards others. Some stereotypes are more favored on the dimension of warmth and less favored on the dimension of competence (Fiske, Cuddy, Glick, \& Xu, 2002).

Interestingly, the positive connotation of accent is reported with western European accents (Lippi-Green, 1994). Compared to Asian or Hispanic accents, Western European accents are generally perceived more positively (Lippi-Green, 1994). Based on Australian children's responses, it was reported that accent of the ethnic groups that were considered dominant or major are more prestigious than the ethnic groups that are considered minors (Nesdale and Rooney, 1996). When students were asked to associate high or low status jobs to candidates' accent, they hierarchically assigned high status jobs to different accents; English accents were assigned the highest status followed by German, South Asian, and West Indian accents (Kalin et al. 1980). Even among participants from Asian, Euro-American, Hispanic American, African American and mixed-ethnicity background, Standard American English (SAE) is considered a reference and often being operationalized as nonaccented English (Hosoda et al. 2007). SAE is known to elicit more positive responses even beyond the group that uses SAE (Hosoda et al. 2007).

To explain such selective favoritism and positive perception of non-native accent, Russo et al. (2016) has proposed potential explanations. Due to dual language proficiency or bilingualism, speakers with non-native accent may experience greater cognitive control (i.e., the "ability to regulate mental activities to resolve information-conflict during processing” [Teubner-Rhodes et al., 2016, p. 213]), 
greater cognitive flexibility (i.e., task switching), and a greater capacity to resolve conflicts (see Bialystok, 2009). Thus speakers with non-native accent as a product of their bilingualism can experience some cognitive advantages to effectively deal with complex work dynamics. Speakers with non-native accent are capable to extract reciprocity effects from their audience as and when listeners appreciate non-native speakers' capacity and effort of using another language (Gouldner, 1960). Current literature in bilingualism has talked about this possibility (Schroeder \& Marian, 2016). Listeners reciprocate by appreciating non-native speakers' skills and ability to execute two different sets of linguistic constructs; examples could be included from literature that explores the positive effects of accent on managers' and non-nativeaccent speakers' work dynamics (Russo, et al., 2016).

Since non-native speakers are already aware that they might be perceived as less competent and could be subjected to negative stereotype, they allocate more resources, effort and perseverance to prove their competencies and disprove irrelevant evaluations based on their accent (Fuertes, Gottdiener, Martin, Gilbert \& Giles, 2012; Roberson \& Kulik, 2007). When speakers with non-native accent realize that listeners' evaluation of speakers' speech quality and inferred intelligence judgment are unrelated, speakers' with non-native accent start suspecting the accuracy of listeners' feedback and engage in feedback discounting (Oppenheimer, 2006). Research on cognitive fluency (Oppenheimer, 2006) has reported that nonnative speakers then attempt to compensate such negative feedback with extra efforts and perseverance (Wilson \& Brekke, 1994).

Literature associating emotions and language has reported that non-native accent, when associated with national identity, can also evoke strong positive affiliations and emotions (Sarter, 2012). Sarter (2012) reported two case studies, one about a Portuguese woman working in France and the other one was about a French working in Germany. Both the women were extremely proud of their national origin and linguistic heritage and reported strong positive emotions while speaking with nonnative accent; they found that listeners would immediately associate their accent with their country of origin and that made them very proud.

Such positive emotional state could also be attained when speakers with nonnative accent enjoy their new-found identity as foreign employees, happily accept their non-native accent or anticipate that their non-native accent could be modified with systematic training and effort and can approximate native-like accent (Gluszek \& Dovidio, 2010a,b).

However, non-native accent-induced positive or negative effects on speakers'cognition, emotions and behaviors vary with the presence of favorable or unfavorable conditions (Russo, M., et al., 2016). Usually, personal (e.g., accent prestige, exposure to a non-native languageand goal orientation) and contextual (e.g., nature of the assignment and organization's ethnocentrism) variables influence such variations in overall outcome (Russo, M., et al., 2016). For example, prestige associated with certain accents is treated favorably (Lindemann, 2005; Mugler, 2002; Ryan, Hewston \& Giles, 1984). Comparably, the accent of the dominant social group is usually favored than accent of the less powerful groups (Anderson et al., 2007). The overall dominance of a social group and hence its accent could be a byproduct of the political clout, the perceived status, power, education, social class, and success associated with the speakers country of origin (Dewaele, 2005; McRae, 1999; Van 


\section{Crossing the Border: International Journal of Interdisciplinary Studies}

Vaerenbergh \& Holmqvist, 2013). For example, the dominant political and economic powers of the world, such as Britain or France are probably considered academic and culturalelites and hence speakers with British and French accents may be rated more favorably as compared to accents from historically marginalized, economically impoverished, or postcolonial countries (Bayard, Weatherall, Gallois \& Pittam, 2001; Cargile \& Giles, 1997; Stewart, Ryan \& Giles, 1985).

Usually, exposure to non-native accents can alter listeners' negative attitudes towards specific accent types. Inspiration to believe such possibility could come from other areas of social science where repeated exposure has shown to moderate listeners intense stereotype-based judgments (Kulik, Brainbridge, \& Cregan, 2008). For example, repeated exposure enhanced observers' attitudes towards a given stimulus (Bornstein \& D’Agostino, 1992; Zajonc 1968) and overgeneralization of such effect was even observed in the visual and linguistic domains (see Bornstein, 1989, for a meta-analysis). Even negative effects of demographic diversity tapers over time because exposure to diversity allows initial stereotype-based impressions to be gradually substituted with rational information about human personalities, skills, and values (Chatman \& Flynn, 2001; Harrison, Price, \& Bell, 1998; Harrison, Price, Gavin, \& Florey, 2002; Sacco \& Schmitt, 2005). Similar findings have been reported where the negative stereotypes of ethnicity (Ball \& Cantor, 1974) and gender (Dasgupta \& Asgari, 2004) have also been shown to be moderated. Repeated interpersonal exposure can minimize the negative 'stigma-by-association' effect and promotes a deeper rational approach on the part of observers (Kulik, Brainbridge and Cregan, 2008).

Similarly, repeated exposure to non-native accents has been reported to promote deeper cognitive processing among the corporate officials (Clarke \& Garrett, 2004; Kulik et al., 2008), and hence they base their evaluations of their employees based on variables not dependent on accent (Gluszek \& Dovidio, 2010a,b). As a consequence employees with non-native accent might also feel less anxious and stressed (Woodrow, 2006), which might enhance the productivity and work-life culture of the corporations. The duration of exposure to non-native accent doesn't have to be long to elicit a differential response. Exposure of a few minutes might enhance rapid listener cognitive adaptation (e.g., Bradlow \& Bent, 2008; Clarke \& Garrett, 2004; Grossman, 2011; see Russo et al., 2016 for a review).

With reference to accent and how speakers deal with their accent, the business management literaturereports that goal orientation could be a critical factor predicting employees' success (Wang \& Takeuchi, 2007). Russo et al., (2016) discusses three types of goal-oriented employees. Employees who are willing to learn new skills and abilities, interpret challenging occasions as opportunities to master new knowledge (Vande Walle, Brown, Cron, \& Slocum, 1999) and frame obstacles or failures as feedback to further expand and refine their competencies (Button et al., 1996) are known as learning-goal-orientated people.Employees who avoid negative judgments, concerned with proving their abilities, prefer simple tasks to prove their competencies rather than complex tasks, are labelled as performance-goal-oriented people (Seijts, Latham, Tasa, \& Latham, 2004). The third category has been labelled as avoidance-goal-orientated as they avoid appearing incompetent. Similar to the performance-goal-oriented people, the avoidance-goal-oriented employees are more concerned with avoiding accent-related stigma, prefer avoiding complex situations 
that expose them to the risk of failures and confirmation of negative stereotypes (Russo, et al., 2016).

Performance and avoidance-goal-oriented people with non-native-accent, usually considertheir accent to be a permanentspeech characteristic and may experience more intense negative emotional reactionsto stigma. Since they also consider that their accent is beyond their control, they usually seek less feedback from supervisors and coworkers. On the contrary, the learning-goal-oriented speakers with accent may seek opportunities to engage in interactions with native speakers to enhance their language-learning experiences and pronunciation skills (Moyer, 2007; Wang \& Takeuchi, 2007) and might feel less embarrassed if corrected on pronunciation.

The nature of communication requirements in a job also influences both listeners or evaluators and the speakers (with non-native accent) or the service providers. That is, if a job requires stronger social communication and pronunciation clarity then speakers with non-native accent might suffer stereotype threat. For example, people with non-native accent who work in call-centers or as a receptionist are probably more prone to consumers' dissatisfaction (Wang et al., 2013).Indian customer service agents attempt to suppress their non-native accent while speaking English to avoid receiving poor ratings by customers (Bordia \& Bordia, 2013). However, jobs where multicultural or multilingual influence is essential, such as for diplomats and for language teachers, non-native accent might establish their credibility andheighten the authenticity of their multiculturalism and multilingualism. In foreign language classrooms, teachers with non-native accent are usually considered better models and those teachers with accent tend to be more empathetic to their pupil's needs (Cook, 2005; Lipovsky \& Mahboob, 2010).

\section{NON-NATIVE ACCENT AND THE LAW}

Globally, there are government rules, regulations and laws to protect citizens and domiciles against discrimination, biases and prejudices. The extent to which those statutes are practiced vary globally and is beyond the scope of this research note. It has been widely accepted that biases are the building blocks of discriminatory attitudes. A bias can be defined as "a particular tendency, trend, inclination, feeling, or opinion, especially one that is preconceived or unreasoned" (dictionary.reference. com, 2015). For example, in the US, Title I and Title V of the Americans with Disabilities Act of 1990, as amended (ADA), prohibit biases against individuals with disabilities. The Civil Rights Act of 1964 (Title VII) prohibits employment discrimination based on race, color, religion, sex, or national origin. The U.S. Equal Employment Opportunity Commission (EEOC) enforces all of these laws to safeguard against consequences of human biases. The Equal Pay Act of 1963 (EPA) protects against sex-based wage discrimination. The Age Discrimination in Employment Act of 1967 (ADEA) prohibits biased action for 40 years of age or older. However, there are no exclusive federal law that protects speakers with nonnative accent against the biases, prejudices and the stereotyping they are frequently subjected to.

In the USA, discrimination based on a person's foreign accent has been prohibited in certain instances under Title VII of the 1964 Civil Rights Act. For accent discrimination litigations, Title VII of The Civil Rights Act of 1964 is used, which prohibits discrimination in employment on thebasis of race, color, religion, 


\section{Crossing the Border: International Journal of Interdisciplinary Studies}

national origin, or gender. The Title VII specifies:

a) It shall be an unlawful employment practice for an employer-(1) to fail or refuse to hire or to discharge any individual, or otherwise to discriminate against any individual with respect to his compensation, terms conditions, orprivileges of employment, because of such individual's race, color, religion, sex, or national origin ....

However, the act does notspecifically mention accent discrimination. The EEOC (U.S. Equal Employment Opportunity Commission), which isresponsibleto enforce TitleVII, has suggested on how to avoid accentdiscrimination. According to EEOC compliance manual, under Title VII, an employer may only makedistinctions on the basis of a person's accent when the accent "materiallyinterferes with the ability to perform job duties" (EEOC 2002). That is, employers have to asktwo questions to themselves (1) does "the ability to communicate in fact materiallyrelate[s] to the ability to perform the job" and (2) does "the individual's accentin fact interferes with that necessary ability to communicate?" If answer to either question is 'no' and the employer has denied employmentopportunities on the basis of the individual's accent, then the employer hasengaged in national origin discrimination, which is an offence (see Smith, 2005 for a review).

According to Smith (2005) the state of U.S. law for accent discrimination and language rights in general, is still not definite and well defined. The scenario is not much different globally with international law for language minorities (SeeDel Valle, 2003). Conventionally, language rights are defined using 2 approaches. (a) The language right is "the right to use one's own language in the course of one's personal human experience," and (b) The second approach "contemplates the protection of linguistic rights not only where language forms the basis of a distinct cultural group, but also in instances of individual assertion of linguistic rights" (Gromacki, 1992). Till date, the most explicit and accent specific international human rights document dealing with language rights statement could be found in the United Nations Charter. Article 1 of that Charter states in part that " $\mathrm{t}$ ]o achieve international co-operation in solving international problems of an economic, social, cultural, or humanitarian character, and in promoting and encouraging respect for human rights and for fundamental freedoms for all without distinction as to race, sex, language, or religion" (U.N. CHARTER, 2000).

Petersen and Boller (2004) reviewed more than 75 court decisions involving "accents"and reported that accent cases are subsumed under the broader category of national origin discrimination. In 2002, 2,700 charges of national origin harassmentwere filed with the EEOC, which is almost double the number of litigations the decade prior (Petersen \& Boller, 2004). The sharp influx in foreignbornemployees, students, the retaliation to the September 11th attack, and the global terroristthreat have all probably differentially contributed to the increase in national origindiscrimination charges.Potential discriminating against speakers with nonnative accent has serious social and economic repercussions, as qualified individuals might be unwillingly compelled to accept low-pay jobs under the pretext of poor intelligibility or comprehensibility. As a consequence, it will not be surprising if we see more litigations related to non-native accent under the veil of national origin discrimination. Thus, more proactive attention and visibility to accent related discrimination is critical in every possible sectors in our society and for professionals 
dealing with accent modification or elimination.

However, in accent discrimination cases plaintiffs are frequently unsuccessful in winning their claim (Smith, 2005). Under the Title VII, it is difficult to prove discrimination and there are numerous cases supporting such difficulty (Smith, 2005). For example, the Sophia Poskocil's case in 1996 (Smith, 2005). Poskocil applied to nineteen teaching positions with Roanoke County schools, but was denied employment based on Northside High School students' evaluations. Students complained that Ms. Poskocil barely spoke English and hard to understand, even though in court no one had difficulty understanding her. The irony was, Ms. Poskocil applied to teach Spanish classes and not English (Smith, 2005). Another famous accent discrimination case where the plaintiff encountered severe roadblock was Fragante v. City \& County of Honolulu, 699 F. Supp. 1429 (D. Haw. 1987), affid, 888 F.2d 591 (9th Cir. 1988; see Smith 2005). The plaintiff was even advised to withdraw the case. This aspect is critical because we are observing a steady influx of nonnative speakers of English into the United States (Smith, 2005). In 1990, 13\% out of the 230.4 million people aged 5 and over, spoke a language other than English at home (U.S. Census Bureau, 1990). In 2000 the number increased to $18 \%$ out of 262.4 million people (U.S. Census Bureau, 2000). In 2010, 21\% out of 291 million people of 5 years of age and above, spoke a language other than English at home (American Community Survey report, Ryan, 2013). Hence, in every sector of our society in the US, in the coming years, we can expect to encounter more speakers of English with non-American accent and potential discrimination associated with non-native accent.

\section{CONCLUSION}

Even though relatively fewer instances are available where speakers with nonnative accent are treated non-discriminately or favored. Highlighting positive instances where speakers with non-native accent have enjoyed relatively higher status might counter the widely reported discriminatory attitude of the listeners. It might reduce the legal complaints and speakers with non-native accent might start feeling more comfortable with the non-nativity in their accent. Since the field of speech language pathology in the recent years has started addressing accent modification therapy, discussion on multiple aspects of accent in different fora might enrich our holistic perspective on accent and its consequences. This is especially critical as biases are not unidirectional and linear, its multivariate, bidirectional and dynamic. Won't it be better to integrate legal immigrants into American society and augment the multilingual milieu which in turn might promote the economic and academic sectors in the USA?

\section{REFERENCES}

Anderson, A., Downs, S. D., Faucette, K., Griffin, J., King, T., \& Woolstenhulme, S. (2007). How accents affect perception of intelligence, physical attractiveness, and trustworthiness. Intuition: BYU Undergraduate of Journal of Psychology, 3, 5-11.

Blake, R., \& Cutler, C. (2003). AAE and variation in teachers' attitudes: A question of school philosophy? Linguistics and Education, 14, 163-194.

Bloch, B., \& Starks, D. (1999). The many faces of English: intra-language variation and its implications for international business. Corporate Communications: An International 


\section{Crossing the Border: International Journal of Interdisciplinary Studies}

Journal, 4(2), 80-88.

Bordia, S., \& Bordia, P. (2013). Mandatory identity imposition and its consequences: The case of linguistic identitymanagement in Indian call centers. Paper presented the Academy of Management Annual Meeting, Orlando, FL.

Brennan, E. M., \& Brennan, J. S. (1981). Measurements of accent and attitude toward Mexican-American speech. Journal of Psycholinguistic Research, 10(5), 487-501.

Brewer, M. B. (1988). A dual process model of impression formation. In T. K. Srull, \& R. S. Wyer (Eds.), Advances in Social Cognition (pp. 1-36). Jr. Hillsdale, NJ: Erlbaum.

Cargile, A. C., \& Giles, H. (1997). Understanding language attitudes: Exploring listener affect and identity. Language \& Communication, 17(3), 195-217.

Chakraborty, R. (2015). An overview of research in Bilingualism: Publication records and global needs. Perspectives in Global Issues in Communications Sciences and Related Disorders, 5, 67-74

Cobb, C. D., \& Glass, G. V. (1999). Ethnic segregation in Arizona charter schools. Education Policy Analysis Archives, 7(1). Available at http://epaa.asu.edu/epaa/v7n1/ DOI: http:// dx.doi.org/10.14507/epaa.v7n1.1999

Corona, O., Hammer, W., Hobbs, S., Martinez, A., Ramirez, C., Chakraborty, R. (2016). Accentbased biases: Review, Exploration and Implications.Research poster at the American SpeechLanguage-Hearing Association Annual Convention in Philadelphia, PA.

Crowl, T. K., \& MacGinitie, W. H. (1974). The influence of students' speech characteristics on teachers' evaluations of oral answers. Journal of Educational Psychology, 66(3), 304.

Dailey R, Giles H, Jansma L. 2005. Language attitudes in an Anglo-Hispanic context: the role of the linguistic landscape. Language \& Communication, 25, 27-38

Dixon, J. A., Mahoney, B., \& Cocks, R. (2002). Accents of guilt? Effects of regional accent, race, and crime type on attributions of guilt. Journal of Language and Social Psychology, 21(2), 162-168.

Edwards, J. (1999). Refining our understanding of language attitudes. Journal of Language and Social Psychology, 18, 101-110.

Edwards, J. R. (1982). Language attitudes and their implications among English speakers. In E. B. Ryan \& H. Giles (Eds.), Attitudes toward language variation (pp. 20-33). London: Edward Arnold.

EEOC Interpretive Manual: Bona Fide Occupational Qualifications, EEOC COMPLIANCE MANUAL (BNA) No. 291, at 625:0004 (Dec. 2002).

Ford, Cecilia E. (1984). The Influence of Speech Variety on Teachers' Evaluations of Students with Comparable Academic Ability, TESOL Quaterly, 25, 26-27.

Fuertes, J. N., Gottdiener, W. H., Martin, H., Gilbert, T. C., \& Giles, H. (2012). A metaanalysis of the effects of speakers' accents on interpersonal evaluations. European Journal of Social Psychology, 42(1), 120-133.

Giles, H., \& Billings, A. C. (2004). Assessing language attitudes: Speaker evaluation studies. The handbook of applied linguistics, 187.

Giles, H., \& Billings, A. C. (2004). Assessing language attitudes: Speaker evaluation studies. The handbook of applied linguistics, 187.

Grossman, L. (2011). The effects of mere exposure on responses to foreign-accented speech. Master's thesis Department of Psychology, San Josè State University.

Fuertes, J. N., Gottdiener, W. H., Martin, H., Gilbert, T. C., \& Giles, H. (2012). A metaanalysis of the effects of speakers' accents on interpersonal evaluations. European Journal of Social Psychology, 42(1), 120-133.

Giles, H. (1970). Evaluative reactions to accents. Educational review, 22(3), 211-227.

Gluszek, A., \& Dovidio, J. F. (2010a). The way they speak: A social psychological perspective 
on the stigma of non-native accents in communication. Personality and Social Psychology Review, 14(2), 214-237.

Gluszek, A., \& Dovidio, J. F. (2010b). Speaking with a non-native accent: Perceptions of bias, communication difficulties, and belonging in the United States. Journal of Language and Social Psychology, 29(2), 224-234.

Goto, S. G., Gee, G. C., \& Takeuchi, D. T. (2002). Strangers still? The experience of discrimination among Chinese Americans. Journal of Community Psychology, 30(2), 211-224.

Granger, R. C., Mathews, M., Quay, L., \& Verner, R (1977). Teacher judgements of the communication effectiveness of children using different speech patterns. Journal of Educational Psychology, 69(6), 793-796.

Hewitt, G. (1971). The Problems of Success: a History of the Church Missionary Society, 19101942: In tropical Africa, the Middle East, at home (Vol. 1). SCM Press.

Hopkins. D. J. (2014). The upside of accents: language, skin tone, and attitudes toward immigration. British Journal of Political Science, 45, 531-557.

Hosoda, M., Stone-Romero, E. F., \& Walter, J. N. (2007). Listeners' cognitive and affective reactions to English speakers with standard American English and Asian accents. Perceptual and Motor Skills, 104(1), 307-326.

Hosoda, M., \& Stone-Romero, E. (2010). The effects of foreign accents on employmentrelated decisions. Journal of Managerial Psychology, 25(2), 113-132.

Kalin, R, Donald S. R, \& Norah L. (1980). The perception and evaluation of job candidates with four different ethnic accents. In Howard Giles, W. Peter Robinson, and Philip M. Smith (eds.), Language: Social Psychological Perspectives, 197-202. Oxford: Pergamon Press.

Kraak, J. M., \& Holmqvist, J. (2016). The authentic service employee: Service employees' language use for authentic service experiences. Journal of Business Research. http:// dx.doi.org/10.1016/j.jbusres.2016.04.182.

Labov, W. (2006). The social stratification of English in New York city. Cambridge University Press.

Lindemann, S. (2005). Who speaks "broken English"? US undergraduates' perceptions of non-native English. International Journal of Applied Linguistics, 15(2), 187-212.

Lippi-Green, R. (1994). Accent, standard language ideology, and discriminatory pretext in the courts. Language in society, 23(02), 163-198.

Lou, R. (1994). Teaching All Students Equally, in Teaching from a Multicultural Perspective 28, 35, Labella \& Axelsen eds., Sage Publications Inc: California.

Matsuda, M. J. (1991). Voices of America: Accent, antidiscrimination law, and a jurisprudence for the last reconstruction. Yale Law Journal, 1329-1407.

Modic, S. (2007). Customers are Fed up with India's Service. Tooling and Production, $73(10), 10-11$.

Moyer, A. (2007). Do language attitudes determine accent? A study of bilinguals in the USA. Journal of Multilingual and Multicultural Development, 28, 502-518.

Ng, S. H., \& Bradac, J. J. (1993). Power in language: Verbal communication and social influence. Sage Publications, Inc.

Oppenheimer, D. M. (2006). Consequences of erudite vernacular utilized irrespective of necessity: Problems with using long words needlessly. Applied Cognitive Psychology, 20, 139-156.

Parkinson B. D. (2007). The Perception of Arab-Accented Speech by American Native Speakers and Non-Native Speakers from East and South-East Asia. Perspectives on Arabic Linguistics xxi: Papers from the Twenty-First Annual Symposium on Arabic Linguistics, 149-162. 


\section{Crossing the Border: International Journal of Interdisciplinary Studies}

Petersen, J. D. \& Boller, H. R. (2004). Accent Cases in Civil Rights Law. Employee Relations Law Journal, 30 (2), 51-61

Rubin, D. L., \& Smith, K. A. (1990). Effects of accent, ethnicity, and lecture topic on undergraduates' perceptions of non-native English-speaking teaching assistants. International Journal of Intercultural Relations, 14(3), 337-353.

Sandberg, J. (2007). 'It says press any key; Where's the any key?': India's call-center workers get pounded, pampered. (February 20). Wall Street Journal (Eastern edition), B1.

Sarter, H. (2012). Language and emotion. In G.Minnini, \&A.Manuti (Eds.). Applied psycholinguistics: Positive effects and ethical perspectives (pp. 61-73). Milano: Franco Angeli.

Shah, A. P. (2012). Accent modification for speakers with Indian accents: Speech characteristics and an assessment framework. SIG 14 Perspectives on Communication Disorders and Sciences in Culturally and Linguistically Diverse (CLD) Populations, 19(1), 12-20.

Smith, G. (2005). I Want to Speak Like a Native Speaker: The Case for Lowering the Plaintiff's Burden of Proof in Title VII Accent Discrimination Cases. Ohio State Law Journal, 66, 231-267.http://hdl.handle.net/1811/71000

Smith, L. E., \& Nelson, C. L. (1985). International intelligibility of English: Directions and resources. World Englishes, 4(3), 333-342.

Stewart, M. A., Ryan, E. B., \& Giles, H. (1985). Accent and social class effects on status and solidarity evaluations. Personality and Social Psychology Bulletin, 11(1), 98-105.

U.S. Department of Commerce, Economics and Statistics Administration, U.S. Census Bureau. (2013, August). Language Use in the United States: 2011 [Press release]. Retrieved from https://www.census.gov/prod/2013pubs/acs-22.pdf

Walsh, E. Catherine. (1991). Pedagogy and the Struggle for Voice: Issues of Language, Power, and Schooling for Puerto Ricans. Praeger.

Wang, M., \& Takeuchi, R. (2007). The role of goal orientation during expatriation: A cross-sectional and longitudinal investigation. The Journal of Applied Psychology, 92(5), 1437-1445.

Wang, Z., Arndt, A. D., Singh, S. N., Biernat, M., \& Liu, F. (2013). "You lost me at hello": How and when accent-based biases are expressed and suppressed. International Journal of Research in Marketing, 30, 185-196.

Wolfram, W. (1999). English with an accent: Language ideology and discrimination in the United States.

\section{ABOUT THE AUTHOR}

Dr. Rahul Chakraborty received his bachelor's degree in Speech Therapy and Audiology and his master's degree in Linguistics, both from Bombay University, India. He earned a doctoral degree from Purdue University in 2006. He teaches undergraduate and graduate courses at Texas State University, USA. He has taught courses at University of Calcutta, India. His interdisciplinary research interests revolve around physiological evidence of first and second language interaction in adult bilinguals. He is the director of Speech kinematics laboratory at Texas State University, USA. E-mail: rc39@txstate. $e d u$ 